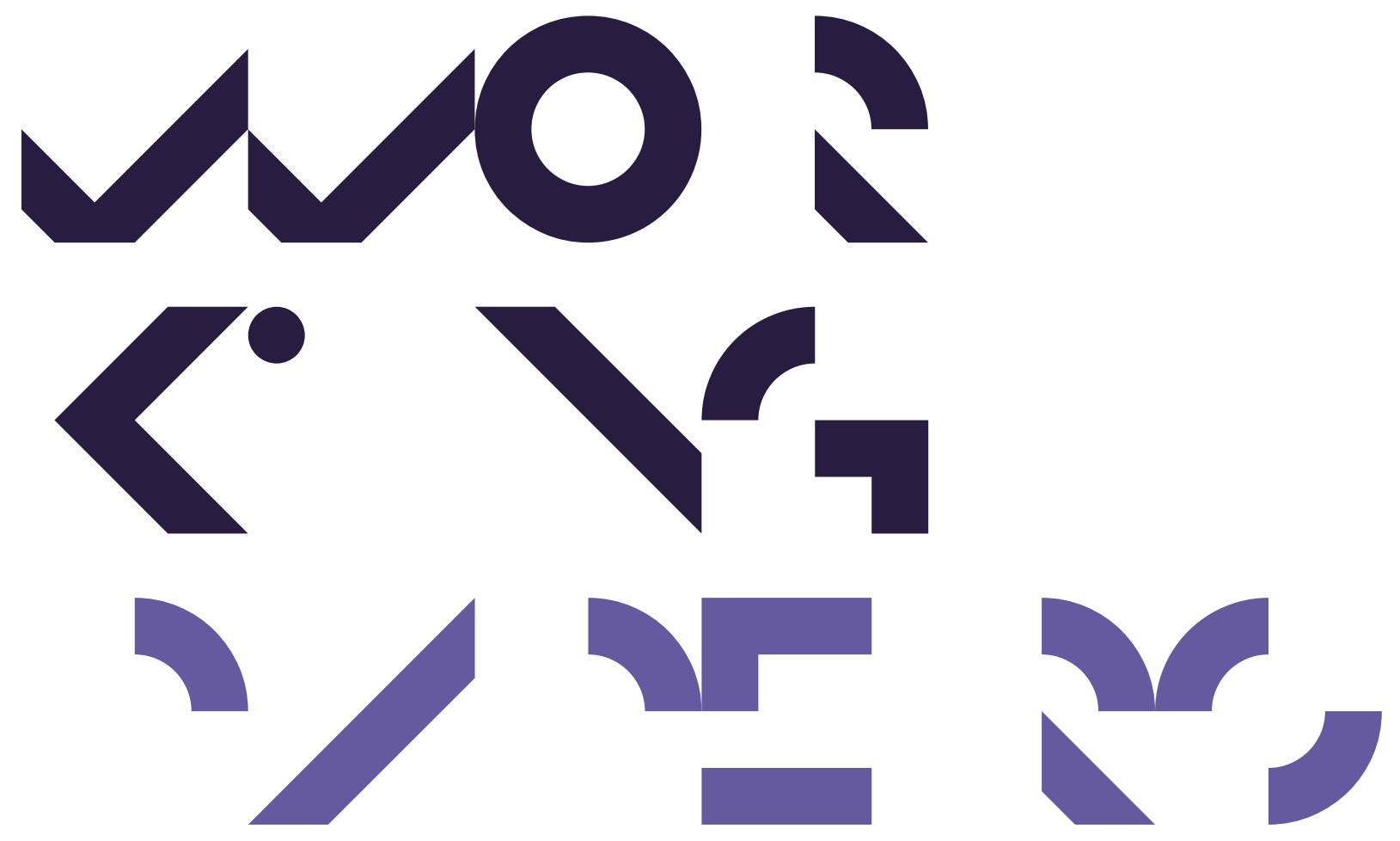

Economics Working Papers

2014-02

The Fertility Transition in the US: Schooling or Income?

Casper Worm Hansen, Peter Sandholt Jensen and Lars Lønstrup 


\title{
The Fertility Transition in the US: Schooling or Income?
}

\author{
Casper Worm Hansen* \\ Peter Sandholt Jensen \\ Lars Lønstrup ${ }^{\dagger}$
}

\begin{abstract}
Schooling. This study estimates the respective contributions of schooling and income in determining the fertility transition within the US states between 1840 and 1980 . While evidence suggests that both relationships are negative and statistically significant, the most robust determinant of the transition is the development of human capital as measured by years of schooling. This empirical fact corroborates the use of the quantity-quality tradeoff mechanism in theoretical models to generate the transition from economic stagnation to growth.
\end{abstract}

Key Words: Fertility transition; Schooling; Income; Q-Q trade-off; US states.

JEL: I2; J11; N3; O11.

\footnotetext{
*Corresponding author: Aarhus University, Fuglesangs Allé 4, 8210 Aarhus V, Denmark, cworm@econ.au.dk.

$\dagger$ University of Southern Denmark, Campusvej 55, 5230 Odense, Denmark. Peter Sandholt Jensen: psj@sam.sdu.dk and Lars Lønstrup: loe@sam.sdu.dk.
} 


\section{Introduction}

Few countries underwent a transition from low to high economic growth without a concurrent transition from high to low fertility. A deeper understanding of the causes of the fertility transition may therefore improve the understanding of the process countries goes through when moving from a stagnant to a growing economy.

In the economic theories of the fertility transition, rising levels of income and schooling play central roles. In the contributions of Becker (1960) and Becker and Lewis (1973) it was shown that higher income may induce parents to have fewer children. These theories emphasize that the quantity and quality of children is a joint decision implying that higher income may cause a fertility decline when the income elasticity of quality is sufficiently high. More recently, the quantity-quality framework has been applied in Unified Growth Theory (Galor, 2011). This theory stresses the role of the emergence of mass education in the fertility transition, i.e. a rising demand for human capital makes parents choose to have fewer children in order to give each child more schooling. ${ }^{1}$

This paper adds new evidence on the determinants of the fertility transition. The analysis exploits data on cohort fertility, cohort years of schooling, and GDP per worker for a panel of 48 US states observed from 1840 to 1980. This allows us to evaluate the relative importance of variation in income and schooling for the fertility decline in the US over the studied period. We find a robust negative relationship between schooling and fertility, while income per worker has no robust relation to fertility.

Our paper relates to three strands of literature. By focusing on the United States, we contribute to the literature on the US fertility transition. The study by Jones and Tertilt (2008) demonstrates a bivariate relationship between income and cohort fertility using US census data from 1828-1960. They conclude that the differences in fertility "can be accounted for by differences in income alone" (Jones and Tertilt 2007, p.52), but do not pursue to evaluate the relative contributions of schooling and income in determining the fertility transition within the US. ${ }^{2}$ Greenwood and Seshadri (2002) seek to explain the US fertility decline with model simulations. They find that the shift towards production of manufactured goods which requires skilled labor, and thus education, together with rising income real wages, which increased the

\footnotetext{
${ }^{1}$ In the theory section below, we give an overview of the existing literature on the fertility transition

${ }^{2}$ They also demonstrate a bivariate negative relationship between human capital and fertility.
} 
time cost of children, were the main drivers of the decline in US fertility. ${ }^{3}$

Our paper is also related to the empirical literature studying the causes of the demographic transition across countries. Recent papers in this literature include Angeles (2010), Herzer et al. (2012) and Murtin (2013). Both Angeles (2010) and Murtin (2013) estimate dynamic panel models. Angeles uses data for 118 country from 1955-2005 and finds that GDP per capita is weakly related to total fertility rates, whereas average years of schooling is negatively and significantly related to total fertility. Murtin (2013) studies the evolution of crude birth rates for the period 1870-2000 and finds primary schooling to be the main determinant for the fertility decline. Herzer et al. (2012) note two weaknesses in the approach taken by Angeles (2010) and Murtin (2013). First, they question the plausibility of assuming common lag structure in a setting with 100 countries. ${ }^{4}$ Second, they point to Roodman (2009), who shows some econometric challenges with GMM panel estimators known as the "too-many-instruments" problem. Herzer et al. (2012) propose to use panel cointegration as an alternative and find that GDP per capita has a negative and significant relation to crude birth rates using crosscountry data from 1900-1999. ${ }^{5}$ In general, our findings are in line with those of Angeles (2010) and Murtin (2013) as we find that schooling is the most important determinant of fertility.

The current analysis is also related to other within-country studies. Becker et al. (2010) use data from Prussia in the 19th century and find an important role for education in generating the fertility decline. In particular, counties in Prussia with higher school enrollment rates in 1849 showed a more rapid decrease in fertility. ${ }^{6}$ Unfortunately, their study does not include controls for income, so the relative importance of the two variables cannot be evaluated. Murphy (2010) studies fertility differences across French regions for the period 1876-1896 and findsin addition to cultural factors - a proxy of income to be positively correlated and a proxy of primary schooling is negatively correlated with family size.

We think that our study has a number of advantages compared to previous research. First,

\footnotetext{
${ }^{3}$ Considering the US in 1850-1860, Steckel (1992) finds that stronger presence of financial institutions and the occupational structure as important for fertility change.

${ }^{4}$ They base this on the "well-known that the lag structure between mortality decline and fertility decline differs widely across countries."

${ }^{5}$ Due to data limitations, Herzer et al. (2012) only include education variables for a smaller subset of countries studied in the 20th century. There they find primary education to be significantly negatively related to fertility.

${ }^{6}$ Becker et al. (2010) also study fertility in a cross-section of Prussian counties in 1849 (before the onset of demographic transition) and find that children's education causes a decrease in fertility. Becker et al (2013) find a negative effect of women's education on fertility in county data from Prussia in 1816, 1849 and 1867.
} 
our data contain decadal observations for the period of 1840-1980, which is a longer coverage than the above-mentioned within-country studies, and covers the entire period of 1870-1920 where most of the fertility transition took place in the majority of present day developed countries (Reher, 2004). ${ }^{7}$ Second, compared to cross-country analyses, the current analysis is less troubled by country heterogeneity, such as institutional and cultural differences and differences in the quality of data. Third, we can better address the concern regarding the assumption of a common lag structure. Finally, as also argued by Jones and Tertilt (2007), the use of cohort fertility as dependent variable is desirable as it provides a more accurate picture of how economic variables affect fertility behavior at a given date compared to period measures such as the total fertility rate.

By employing static and dynamic panel models using both fixed effect and GMM estimation strategies, we find a robust negative relationship between schooling and fertility for cohorts between 1840-1980. Our estimates suggests that one additional year of schooling of a child means that the child had $0.15-0.30$ fewer siblings. The coefficient on income per worker is not robust: fixed effect estimates suggest a negative effect whereas a dynamic panel framework estimates a positive effect. Our findings are in line with qualitative accounts that emphasize that the transition to sustained growth in the US was characterized by an increase in the importance of human capital, e.g. Galor (2011, p.56).

The rest of the paper is organized as follows. Section 2 summarizes the main hypotheses to be investigated. Section 3 describes the data used. Section 4 presents the empirical strategy. Section 5 contains our main findings and robustness checks. Finally, Section 6 concludes.

\section{Theory}

This section offers a concise survey of the theories that motivate our empirical strategy. Since the focus of this analysis is to test how changes in income and education relate to the US fertility transition, we focus on theories that highlight their importance. Moreover, we also briefly survey theories that motivate the use of mortality as an explanatory variable in the empirical model. ${ }^{8}$

\footnotetext{
${ }^{7}$ Since we have data for the 48 contiguous states from 1840 we use more variation from the 19 th century that most of the existing studies.

${ }^{8}$ For a more elaborate review of the literature on the fertility transition, see Galor (2011)
} 


\subsection{Income and fertility}

Motivated by the negative cross sectional correlation between income and fertility in developed countries (see Jones and Tertilt, 2007) a significant body of theoretical work, pioneered by the contributions by Becker (1960) and Becker and Lewis (1973), suggests that rising income is causing declining fertility. The important insight from these papers is that the (shadow) price of children depends on the level of quality of each child, which is an endogenous variable. Thus, even if children is a "true" normal good, one will observe that richer parents have fewer children if the income elasticity of child quality is sufficiently high. ${ }^{9}$

Together with the quantity-quality trade-off, the time cost of children is the most commonly employed mechanism in the theoretical literature that seeks to explain a negative effect of income on fertility. Increases in parents' wages imply that families can afford more children, but each child is more costly to raise since the value of time has increased, and therefore, if the substitution effect is larger than the income effect, income and fertility are negatively related. The curvature of the utility function is thus crucial for the predictions of this theory. However, the effect may operate solely through the family budget. If family income comprises more sources than the income from the parent(s) who spend time on child rearing, the price of child rearing will increase more than total family income. One example of this argument is made by Galor and Weil (1996). However, rather than the level of income, they stress the importance a narrowing gender wage gap during the process of industrialization for the concurrent decline in the fertility. ${ }^{10}$

\subsection{Schooling and fertility}

There are a number of reasons why schooling and fertility are negatively correlated from a theoretical perspective. Galor and Weil (2000) focus on education as the quality of children in a quality-quantity framework. They argue that rising demand for human capital during industrialization triggered parents to have fewer and better educated children and thus a fertility transition. In their theory, the fertility transition and economic transition are interdepen-

\footnotetext{
${ }^{9}$ Becker and Tomes (1976) provide an example of why this may be the case based on a specific functional form of the production function for quality. For a detailed presentation of the theories see Jones, Schoonbroodt, and Tertilt (2011)

${ }^{10}$ Due to data limitations, we cannot test the importance of the gender wage gap. For evidence in line with this hypothesis, see Schultz (1985).
} 
dent: lower fertility is due to more education which spurs technological progress which further increases education and lowers fertility. This effect of education on fertility via the quantityquality trade-off is also present in later contributions within Unified Growth Theory, such as Galor and Moav (2002), Doepke (2004) and Cervellati and Sunde (2013). ${ }^{11}$ Additionally, since Cochrane (1979), it has been widely recognized that there is a negative correlation between parents' level of education and fertility is well established. Various mechanisms that link these variables have been suggested in the literature. Possibly, parental education may affect fertility via its effect on income through the above mentioned channels. However, some theories suggest additional channels through which higher education leads to lower fertility. One example is Moav (2005) who argues that better educated parents have a comparative advantage in the production of child quality, implying that better educated parents have fewer children and provide more schooling to each child more. In addition, the time devoted to children may leave less time to human capital accumulation (either formal schooling or on the job training) which directly creates a negative relation between the variables, a mechanism which is present in e.g. Cervellati and Sunde (2013). ${ }^{12}$

\subsection{Mortality and fertility}

Demographers have focused on the decline in mortality as an explanation of the fertility transition. This line of research is build upon the observation that, for most countries, a drop in mortality is observed before the onset of the fertility transition. As a consequence, the demographic transition theory explains the rapid growth of population in the first stage of the demographic transition as a delayed response in fertility to the drop in mortality. ${ }^{13}$

\footnotetext{
${ }^{11}$ This effect is also present in de la Croix and Doepke (2003), studying the effect of inequality on growth from differential fertility. Caldwell (1980) describes potential channels through which children's education might affect fertility.

${ }^{12}$ While the mentioned theories argue that the causal link goes from education to fertility, work by e.g. Angrist and Evans (1998) and Cohen et. al (2011) show evidence of childbearing having a negative effect on education of mothers. Thus, there may be two-way causation, both in the context of a quantity quality trade-off and in the trade-off parents face between their own education and the number of children they have. See also Bloom et al. (2009) considering the effect of fertility on female labor supply

${ }^{13}$ The United States, together with France, are known to be exceptions, where fertility started to decline before mortality (Haines, 1994). This does not rule out the possibility that a drop in mortality causes lower fertility, but it suggest that this is not the only effect.
} 
If parents target a certain number of surviving children there is a mechanic effect of infant (child) mortality on fertility: a drop in mortality of children would mean that fewer births are needed to reach the desired target. In addition to this, Kalemli-Ozcan $(2003 ; 2008)$ argues that the decline in the uncertainty of the survival rates of children, entailed by lower child mortality, leads parents to decrease their precautionary demand for children. Doepke (2005) studies this in a dynamic setting and finds that the precautionary motive cannot account for the decline in the number of surviving children during the fertility transition due to a replacement effect. ${ }^{14}$ Furthermore, fertility and child mortality may be positively correlated due to a trade off parents face between health investment per child and how many children to have (see e.g. Strulik, 2004, 2008; and Birchenall, 2007)

In addition to being an independent causal factor of the fertility decline, mortality may be a channel through which education and income affects fertility. For example, education of parents may lower infant and child mortality and thereby fertility, since fewer births are needed to acquire the desired number of surviving offspring (Lam and Duryea, 1999; Schultz, 1994).

\section{Data}

This section describes the dataset used in the analysis. The variables are measured with 10 years interval which corresponds to 1 period in our empirical model. We use information on the number of children ever born to married white women between the ages 35 and 44, sampled at date $\tau$ in the US Census. ${ }^{15}$ Assuming that the fertility decisions for this cohort of women, on average, was determined 20 years prior to $\tau$, we construct our fertility variable Children $_{s, t}$, which we assume was influenced by the economic conditions in state $s$ around year $t=\tau-20$ years. For example, Children $_{s, 1900}$ is then equal to the number children ever born to married white women between the ages 35 and 44 sampled in 1920.

To test whether fertility in a given period varies with the level of schooling obtained during life of the cohort of born in that period, we use a cohort based measure of human capital: average years of schooling for the cohort born in year $t+4$ years, $S c h o o l_{s, t}$. For example, $S_{c h o o l}, 1900$ gives information on years of schooling for the birth cohort of 1904, who started

\footnotetext{
${ }^{14}$ That is, parents have the opportunity to have more children after the mortality rate of the children already born is known.

${ }^{15}$ We obtain these data from Tamura (2012).
} 
in the schooling system in 1910, across the US states. We use this measure in our baseline estimations to capture a quantity-quality trade-off as discussed in section 2.2. We also present estimates using a cross-sectional measure -i.e., average years of schooling in the workforce in year $t$. We use the second measure for two reasons. First, average years of schooling in the workforce arguably proxies for parental education, and theory predicts that the human capital level of the parents is negative linked to the number of offsprings. This implies that the effect of School/worker ${ }_{s, t}$ should be distinguishable from that of our basic human-capital measure and this allows us to engage with the theories that emphasize parental education. Second, average years of schooling are employed in other studies, and we can use this for comparability. To capture the effect of income, we use log GDP per worker to capture the income level of state $s$ in year $t$. Moreover, we use the probability of dying for a white individual before the age 15 and the probability of a white individual surviving to the age 60, conditional on surviving to age 15, to control for the mortality environment in year $t$.

Figures 1-3 depict how the three key variables changed in the period of observation from 1840 through 1980. Figure 1 shows that from a state average of 4.99 children per woman in $t=1870$, US fertility declined to a level of 2.25 children per woman in the 1930s. This was followed by a baby boom and baby bust, but the fertility level in the baby-boom years 19501960 did not exceed the pre-1910 level. As shown in Figure 2, the trends in schooling seems to be inversely related to fertility changes: it was increasing steadily from 1860 through 1920, whereas from 1930 to 1980 the time path is U-shaped. In Figure 3, we observe that income levels were generally rising during the observation period, although there were some year-to-year fluctuations, in particular, before World War II. Figures 4 and 5 show scatter plots between fertility and schooling and fertility and income. They also indicate that the unconditional relationships are negative.

Figures 1-5 about here

\section{Empirical Strategy}

In this section, we describe our econometric specifications. Our approach is to estimate a panel data model with state fixed effects and time effects while also allowing for dynamics in fertility. We follow two strategies to investigate the effect of schooling and income on fertility. 
The first strategy controls for state and time fixed effects, which take into account that the US states differ in many permanent characteristics that we do not observe and which may also affect education and income. This model specification is presented in Section 4.1. The second strategy allows for mean-reverting dynamics and persistent effects in fertility that may be endogenous to income and education. ${ }^{16}$ In particular, we estimate the coefficients in equation (1) by system GMM using 30-70 year lags in the explanatory variables as the "within" instruments. This model specification is presented in Section 4.2 .

\subsection{Fixed Effects model}

The empirical specification for the fixed effects model is given by:

$$
\text { Children }_{s, t}=\beta \text { School }_{s, t}+\gamma \log G D P / \text { worker }_{s, t}+\mathbf{Z}_{s, t}^{\prime} \eta+\tau_{t}+\lambda_{s}+\varepsilon_{s, t},
$$

where Children $_{s, t}$ is the average number of children per woman born around year $t$ in state $s$, School $_{s, t}$ is years of schooling for the cohort of white individuals born around year $t$, $G D P /$ worker is the gross domestic product per worker in constant 2000 dollars, and $\mathbf{Z}_{s, t}^{\prime}$ denotes a vector of other controls, which, for example, includes information on the cross-sectional mortality patterns in the ages from $0-15$ and 15-60, respectively. Finally, $\tau_{t}$ and $\lambda_{s}$ denote the unobserved time and state fixed effects, and $\varepsilon_{s, t}$ is the error term. Model (1) is estimated utilizing a panel of 48 US states, consisting of observations at 10 year intervals between 1840 and 1980.

\subsection{System GMM}

In order to disentangle the income-fertility schooling-fertility relationships, we now consider the following dynamic specification:

$$
\begin{gathered}
\text { Children }_{s, t}=\alpha \text { Children }_{s, t-1}+\beta \text { School }_{s, t}+\gamma \log \text { GDP/worker }_{s, t}+ \\
\mathbf{X}_{s, t}^{\prime} \eta+\tau_{t}+\varepsilon_{s, t} \\
\varepsilon_{s, t}=\mu_{s}+v_{s, t}
\end{gathered}
$$

\footnotetext{
${ }^{16}$ This addresses concerns about persistence of e.g. cultural factors or social norms.
} 
where the variables are defined as above, though we let $t=1,2, . ., T$, where each period is a decadal observation. We estimate equation (2) by the system GMM estimator, where all covariates are treated as endogenous. We apply the system GMM estimator which requires instruments $w_{i t}$ satisfying $E\left(w_{i t} \Delta \varepsilon_{s, t}\right)=0$ and $E\left(\Delta w_{i t} \varepsilon_{s, t}\right)=0$ for consistency, see Roodman (2009). In the absence of serial correlation in $v_{s, t}$ (i.e. no second-order serial correlation in $\Delta v_{s, t}$ ) appropriately lagged values of the dependent variable and the covariates are valid instruments for the differenced equation and differenced variables can be used as instruments for the variables in the level equation. Murtin (2013) chooses $w_{i t}=y_{i, t-l}$ for $l \geq 3$ and $\Delta w_{i t}=\Delta y_{i, t-1}$ for $t \geq 4$ with the maximum lag set to the 7th lag. These choice amount to using 30-70 year lags. However, these choices may lead to "too many instruments" as noted by Roodman (2009) and weak power of J-tests of over-identifying conditions. A solution is to extract principal components of the original instrument set in order to reduce the number of actual instruments as to avoid the problem of "too many instruments". ${ }^{17}$ We adopt this solution using 30-70 years lags for instruments. We note that our results do not depend on using principal components but it only serves to reduce the problems with J-tests. Finally, it is important to consider the conditions under which we can attribute a causal interpretation to our estimated coefficients. This requires that the model has been correctly specified and that lagged values of the variables are valid instruments. Since our instruments date 30 years or more back in the past, the exclusion restrictions seem plausible which warrants a causal interpretation. However, since we do not have credible exogenous sources of variations in schooling and income, one could argue that we are simply using the GMM estimator to remove the mechanical bias resulting from the presence of fixed effects and lagged dependent variable. This would mean that what we find are 'robust correlations' (Acemoglu et al., 2013).

\section{Results}

This section presents the results. We first discuss the results based on Pooled and Fixed Effects OLS estimation in section 5.1. Then System GMM results follow in section 5.2.

\footnotetext{
${ }^{17}$ Roodman (2009) himself has implemented these in his STATA module for estimating dynamic panel models using GMM.
} 


\subsection{Pooled OLS and Fixed Effects Results}

Table 1 provides the results of estimating equation (1) by pooled OLS. For consistency, this estimation method requires that the explanatory variables are unrelated to the composite error $\nu_{s, t}=\lambda_{s}+\varepsilon_{s, t}$, conditional on the common time trends across the US states, that is, $E\left(\nu_{s, t} \mid \mathbf{X}_{s, t}^{\prime}\right)=0$, where $\mathbf{X}_{s, t}^{\prime} \equiv\left(\right.$ School $_{s, t}, \log G D P /$ worker $\left., \mathbf{Z}_{s, t}^{\prime}, \tau_{t}\right)$. All regressions include timefixed effects. Column 1 starts by only including the cohort schooling variable. The estimated coefficient shows a significant decrease in fertility associated with the increase in years of schooling over the last 140 years. Column 2 demonstrates a corresponding result for income. The next two columns contain $S_{c h o o l}$ s,t and log GDP/worker at the same time, but without and with controls for mortality, respectively. The coefficients on both variables are negative, statistically significant, and similar in magnitude to the univariate results from the first two columns. Adding the 10-year lag of Children reduces the statistically significance of the coefficient on log GDP per worker, while the human-capital variable retains its significance (column 5). Furthermore, in comparison to the estimates in the former columns, the magnitudes of the effect of both variables are decreased.

Table 2, which parallels the structure of the first table, presents our basic results but with state fixed effects. The fixed effects estimator will be consistent if $E\left(\varepsilon_{s, t} \mid \mathbf{X}_{s, t}^{\prime}, \lambda_{s}\right)=0$. Thus, this estimation method does not hinge upon the assumption that the explanatory variables are orthogonal to the state fixed effects. As seen, the estimates paint a similar picture as when fixed effects are not included in the regressions. For example, in the specification presented in column 4 , the effect of schooling on the number of children per woman is -0.15 with a standard error of 0.03. Taken at face value, the estimate implies that one additional year of schooling reduces the number of siblings by 0.15 , suggesting that the rise in schooling from 3.3 to 13.95 years over the period 1840-1980 explains 55 percent of the US fertility transition. In comparison, the international evidence presented in Murtin (2013) suggests that when average years of primary schooling in the workforce increase from 0 to 6 years, the fertility rate decreases by $40-80$ percent. Moreover, considering 16 advanced countries, he finds that the 1870-1910 increase in schooling was behind 8.8 percent of the decrease in the fertility rate. Our estimate suggests 23 percent of the decline in the number of children per white woman is explained by the rise of schooling in the cohorts between 1870 and 1910. Table 2 also shows that the effect associated with a 10 percent increase in GDP per worker is -0.05 , which is statistically significant at 1 percent level. In the last column of table, we include the lagged outcome variable Children $_{s, t-1}$. 
While the fixed effect estimator by construction is biased, $\operatorname{Cov}\left(\operatorname{Children}_{s, t-1}, \varepsilon_{s, t}\right) \neq 0$, and the estimate therefore must be interpreted with caution, the regression coefficients associated with schooling and income remain negative and significant, although they decrease in magnitude as in Table 1.

Overall, the initial results indicate that both schooling and income were significant determinants of the US fertility decline over the period 1840-1980. However, questions regarding the interpretation of the estimates remain unanswered. For example, it is possible that $\operatorname{Cov}\left(\mathbf{X}_{s, t}, \varepsilon_{s, t}\right) \neq 0$ because of a reverse causality: lower fertility naturally leads to lower population size, which, in a decreasing return to scale economy tends to increase the level of income. Moreover, the fixed effect estimator might be inconsistent if unobserved time varying variables are correlated with the regressors in the model. For example, social norms which correlate with our observables may persist over time and this may lead to persistence in fertility. In the following, we consider alternative estimation strategies to deal with such issues.

\section{Tables 1 and 2 about here}

Table 3 reports the System GMM regressions of equation (2). In column 1, we include the schooling variable along with the lagged dependent variable. The estimate on $S_{c h o o l}$ is -0.24 with a standard error of 0.08 , so the GMM estimate is significantly larger in numerical magnitude compared to the previous fixed effect estimates. The estimate of $\alpha$ implies that the long-run effect of one additional year of schooling is $-0.24 /(1-0.48)=-0.46$. Column 2 reveals that in this dynamic System-GMM framework, the effect of income on fertility is effectively zero: $\hat{\gamma}=-0.1$ with a standard error of 0.15 . Thus, the negative fixed effect estimates - presented in the previous subsection - are not robust to this alternative estimation strategy, suggesting that the rise of income within US states cannot be attributed as a fundamental factor in the US fertility transition. In column 3, we enter schooling and income together, along with the mortality variables - i.e., we now study the full model as specified in equation (2). While the estimated coefficient on years of schooling remains stable in both magnitude and statistical significance, the sign of the coefficient on $\log G D P /$ worker changes from negative to positive and becomes statistically significant at the 10 percent level. The first four columns of the table utilize lags between three and seven time periods as instruments (i.e., the variables lagged 30-70 
years). In column 4, we change this to between three and four lags. This actually raises the magnitude of the estimate on income to 0.43 with a standard error of 0.26 , whereas in the 30-70 years lag model, the same coefficient was estimated as 0.26 with a standard error of 0.16. Still, the relationship between schooling and fertility remains unchanged. Finally, it is notable from the bottom of table 4 that all the regressions pass the tests of first and second-order serial correlation. First order serial correlation is present in the differenced residuals whereas, second order serial correlation cannot be detected. This is in line with the modeling assumptions of the estimators. Moreover, the specifications in columns 1, 3, and 4 are accepted with respect to the validity of their instruments with p-values that are not implausibly high suggesting that we effectively address the concern regarding the "too-many-instruments" problem. We note that the model in column (2) which only include log GDP/worker appears misspecified as the J-test rejects the validity of the over-identifying restrictions.

Thus, the evidence reported in Table 3 demonstrates that the rise in human capital is the primary cause of the fertility transition, while the increase in income seems to be positively related to fertility.

\section{Table 3 about here}

\subsection{Robustness analysis}

This sections presents various extensions to the baseline fixed effect and System GMM results reported in the previous section. Table 4 investigates further channels through which schooling could affect fertility.Based on the arguments presented in section 3 we now consider the effect of the average schooling years in the workforce, School/worker ${ }_{s, t}$ on fertility. Considering the basic specification, columns 1 and 3 replace cohort schooling with average years of schooling in the workforce, whereas columns 2 and 4 augment the basic model with it. The effect of schooling years in the workforce on fertility is negative and significant throughout all four specifications. For example, when $\mathrm{School}_{s, t}$ is not included, column 3 shows that the coefficient estimated by system GMM is -0.30 with a standard error of 0.01 . Moreover, as expected, the effect of schooling years by cohort is reduced once we control for School/worker ${ }_{s, t}$. However, reassuringly, the coefficient retains the negative sign and is statistically significant at the one percent level. The system GMM estimate, reported in column 4, implies that the rise in human capital between 1840 and 1980, as measured by $S c h o o l_{s, t}$, accounts for about 50 percent of the 
fertility transition. We note that the test statistics associated with System GMM method in the full model in column (4) is passed, but the the p-value of the Hansen-J test has a value of 0.157 which is lower than in our baseline specification. 0.156 ; see the bottom of column $4 .{ }^{18}$ In sum, the evidence in Table 4 indicates that level of human capital of the parents as well as the human capital level of their children are negative related to the number of children born per woman.

\section{Table 4 about here}

Table 5 demonstrates that our basic conclusions are robust across alternative time periods. Columns 1 and 3 look at the pre-World War II period, while the remaining columns pertain to the 20th century (i.e., between 1900 and 1980). We find a consistent negative effect of schooling on fertility behavior, both in the fixed effects and the System GMM regressions. Further, the coefficient estimate on the level of log GDP per worker becomes positive when applying the system GMM estimator, which is consistent with our baseline conclusion (see column 4).

\section{Table 5 about here}

A priori, it is not clear whether schooling and fertility should be specified in logs or levels. For this reason, Table 6 presents fixed effects and system GMM estimates for different functional forms. The results show negative and significant effects regardless of whether human capital is measured in years of schooling or log years of schooling, and regardless of whether fertility is measured levels or logs. The model specifications reported in columns 1 and 3 have the same functional forms as the baseline model in Murtin (2013). He estimates the effect of schooling on fertility from -0.11 to -0.04 , whereas the US evidence indicate that the effect is close to -0.06 (i.e., the fixed effect estimate is -0.04 and the system GMM is -0.07), and a similar estimate is recovered using average years of schooling in the workforce. Finally, the coefficient estimates on log GDP per worker parallel those presented in the former tables.

\section{Table 6 about here}

\footnotetext{
${ }^{18}$ When we do not include the cohort based schooling measure, the model appear misspecified according to the Hansen J-statistic, see column 3.
} 


\section{Conclusion}

This research studies the determinants of the fertility transition in a panel of the 48 contiguous US states. While the initial results from OLS estimations suggest that the rise of schooling and income both are related to the observed decrease in US fertility during the period 18401980, allowing for mean-reverting dynamics and persistent effects in fertility, which may be endogenous to income and schooling, demonstrates the primacy of the development in schooling over income in the fertility transition. We estimate that about 50 percent of the fertility decline over past two centuries can be attributed to the rise in schooling during this period. Moreover, the evidence is consistent with the quantity-quality tradeoff and a role for parental education.

Future research which should look for some plausible exogenous variation in schooling across time and states to study the causal effect on fertility. However, this makes it hard to compare the effect of schooling to that of income as such a comparison also requires exogenous variation in income. For this reason, we believe that the our study makes an important contribution in evaluating the relative importance of income and schooling in the US fertility transition. 


\section{References}

[1] Acemoglu, D., Suresh, N., Pascual. R., Robinson, J.A. (2013). Democracy, Redistribution and Inequality. NBER Working Paper No. 19746

[2] Angeles, L. (2010). Demographic transitions: Analyzing the effects of mortality on fertility. Journal of Population Economics, 23, 99-120.

[3] Angrist, J.D., Evans, W.N. (1998). Children and Their Parents' Labor Supply: Evidence from Exogenous Variation in Family Size. American Economic Review, 88(3), 450-77.

[4] Becker, G.S. (1960). An economic analysis of fertility, in G.S. Becker (ed.) Demographic and economic change in developed countries.

[5] Becker, G.S., Lewis, H.G. (1973). On the interaction between quality and quantity of children. Journal of Political Economy 81(2), 279-288.

[6] Becker, G.S., Murphy, K.M., Tamura, R. (1990). Human capital, fertility, and economic growth. Journal of Political Economy 98(2), 12-37.

[7] Becker, G.S., Tomes, N. (1976). Child Endowments and the Quantity and Quality of Children. Journal of Political Economy 84(4), 143-S162.

[8] Becker, S.O., Cinirella, F., Woessman, L. (2010). The trade-off between fertility and education: evidence from before the demographic transition. Journal of Economic Growth $15(3), 177-204$.

[9] Becker, S.O., Cinirella, F., Woessman, L. (2013). Does Women's Education Affect Fertility? Evidence from Pre-Demographic Transition Prussia. European Review of Economic History, 24-44.

[10] Bloom D.E., Canning, D., Fink, G (2009). Fertility, female labor force participation, and the demographic dividend. Journal of Economic Growth, 14(2), 79-101.

[11] Birchenall, J.A. (2007). Escaping high mortality. Journal of Economic Growth, 12(4), 351387.

[12] Caldwell, J.C. (1980). Mass Education as a Determinant of the Timing of Fertility Decline. Population Studies, 37(2),185-205. 
[13] Cochrane, S.H., (1979). Fertility and Education: What Do We Really Know? Baltimore: Johns Hopkins University Press.

[14] Cohen J.E, Kravdal, Ż., Keilman, N. (2011) Childbearing impeded education more than education impeded childbearing among Norwegian women. Proceedings of the National Academy of Sciences 108(29), 11830-11835.

[15] Cervellati M., Sunde, U. (2013). The Economic and Demographic Transition, Mortality, and Comparative Development. IZA DP No. 7199.

[16] de la Croix., D., Doepke, M. (2003). Inequality and Growth: Why Differential Fertility Matters. American Economic Review 93(3), 1091-1113.

[17] Doepke, M. (2004) Accounting for Fertility Decline During the Transition to Growth," Journal of Economic Growth 9(3), 347-383.

[18] Doepke, M. (2005). Child mortality and fertility decline: Does the Barro-Becker model fit the facts?," Journal of Population Economics,18(2), 337-366.

[19] Galor, O., (2011). Unified growth theory. Princeton University Press.

[20] Galor, O., Moav, O. (2002). Natural selection and the origin of economic growth. Quarterly Journal of Economics 115(2), 469-497.

[21] Galor, O., Weil, D.N. (1996). The gender gap, fertility, and growth. American Economic Review 86(3), 374-387.

[22] Galor, O., Weil, D.N. (2000). Population, Technology, and Growth: From Malthusian Stagnation to the Demographic Transition and Beyond. American Economic Review 90(4), 806-828.

[23] Greenwood, J., Seshadri, A. (2002). The U.S. Demographic Transition. AEA PAPERS AND PROCEEDINGS, 153-159.

[24] Haines, M.R. (1994). The Population of the United States, 1790-1920". NBER Historical Working Paper No. 56.

[25] Herzer, D., Strulik, H., Vollmer, S. (2012). The long-run determinants of fertility: one century of demographic change 1900-1999. Journal of Economic Growth 17(4), 357-385. 
[26] Jones, L.E., Tertilt, M. (2008). An Economic History of Fertility in the U.S.:1826-1960. In (ed) Rupert, P, Frontiers of Family Economics vol. 1. Emer- ald Press.

[27] Jones, L.E., Schoonbroodt, A. Tertilt, M. (2011). Fertility Inefficiencies and Development. 2011 Meeting Papers 369, Society for Economic Dynamics.

[28] Kalemli-Ozcan, S. (2003). A stochastic model of mortality, fertility, and human capital investment. Journal of Development Economics, 70(1), 103-118.

[29] Kalemli-Ozcan, S. (2008). The uncertain lifetime and the timing of human capital investment. Journal of Population Economics, 21(3), 557-572.

[30] Lam, D., Duryea, S. (1999). Effects of schooling on fertility, labor supply, and investments in children, with evidence from Brazil. Journal of Human Resources, 160-192.

[31] Moav, O. (2005). Cheap Children and the Persistence of Poverty. The Economic Journal $115(500), 88-110$.

[32] Murtin, F. (2013). Long-term Determinants of the Demographic Transition: 1870-2000. Review of Economics and Statistics 95(2), 617-631.

[33] Murphy, T. (2010). Old Habits Die Hard (Sometimes). Can département heterogeneity tell us something about the French fertility decline?, Working Papers 364, IGIER (Innocenzo Gasparini Institute for Economic Research), Bocconi University.

[34] Reher, D.S. (2004). The Demographic Transition Revisited as a Global Process. Population, Space and Place 10, 19-41

[35] Roodman, D. (2009). A Note on the Theme of Too Many Instruments. Oxford Bulletin of Economics and Statistics 71(1), 135-158.

[36] Strulik, H (2004). Child mortality, child labour and economic development. The Economic Journal 114(497), 547-568.

[37] Strulik, H (2008). Geography, health, and the pace of demo-economic development. Journal of Development Economics 86(1), 61-75. 
[38] Steckel , R. (1992). The Fertility Transition in the United States. Tests of Alternative Hypotheses. In Goldin, C., Rockoff, H. (eds), Strategic Factors in Nineteenth Century American Economic History: A Volume to Honor Robert W. Fogel. Chicago, University of Chicago Press.

[39] Schultz, T.P., (1985). Changing World Prices, Women's Wages, and the Fertility Transition: Sweden, 1860-1910. Journal of Political Economy, 1126-1154.

[40] Schultz, T.P. (1994). Human capital, family planning, and their effects on population growth. The American Economic Review, 84(2), 255-260.

[41] Tamura, R., Curtis, S., Murphy K.M. (2012). Black and White Fertility, Differential Baby Booms: The Value of Civil Rights, MPRA Paper No. 40921.

[42] Wahl, J. (1992). American Fertility Decline in the Nineteenth Century: Tradeoff of Quantity and Quality? In Goldin, C., Rockoff, H. (eds), Strategic Factors in Nineteenth Century American Economic History: A Volume to Honor Robert W. Fogel. Chicago, University of Chicago Press. 


\section{Table 1-Pooled OLS estimates}

\begin{tabular}{|c|c|c|c|c|c|}
\hline & (1) & $(2)$ & $(3)$ & $(4)$ & $(5)$ \\
\hline & \multicolumn{5}{|c|}{ Dependent variable is Children } \\
\hline School & $\begin{array}{c}-0.296 * * * \\
(0.0465)\end{array}$ & & $\begin{array}{c}-0.236^{* * *} \\
(0.0462)\end{array}$ & $\begin{array}{c}-0.202^{* * *} \\
(0.0419)\end{array}$ & $\begin{array}{c}-0.0864^{* * *} \\
(0.0196)\end{array}$ \\
\hline Log GDP/worker & & $\begin{array}{c}-0.734^{* * *} \\
(0.0905)\end{array}$ & $\begin{array}{c}-0.574^{* * *} \\
(0.0767)\end{array}$ & $\begin{array}{c}-0.536^{* * *} \\
(0.0881)\end{array}$ & $\begin{array}{l}-0.124^{*} \\
(0.0627)\end{array}$ \\
\hline Children $_{t-1}$ & & & & & $\begin{array}{c}0.713^{* * *} \\
(0.0525)\end{array}$ \\
\hline Mortality 0-15 & & & & $\begin{array}{c}-3.125^{* *} \\
(1.250)\end{array}$ & $\begin{array}{c}-0.802^{*} \\
(0.434)\end{array}$ \\
\hline Mortality $15-60$ & & & & $\begin{array}{c}2.545^{* * *} \\
(0.878)\end{array}$ & $\begin{array}{l}0.537 \\
(0.339)\end{array}$ \\
\hline Time Fixed Effects & Yes & Yes & Yes & Yes & Yes \\
\hline State Fixed Effects & No & No & No & No & No \\
\hline \# of States & 48 & 48 & 48 & 48 & 48 \\
\hline \# of Observations & 687 & 665 & 665 & 661 & 633 \\
\hline
\end{tabular}

Notes: The table reports OLS estimates. The unit of observation is US state over the period 1840-1980. The dependent variable is the number of children ever born by a white woman. The explanatory variables are defined in the Data Appendix. Constants are not reported. Standard errors clustered by state in parentheses.

*** $\mathrm{p}<0.01,{ }^{* *} \mathrm{p}<0.05,{ }^{*} \mathrm{p}<0.1$. 
Table 2-Baseline Fixed-Effects Estimates

\begin{tabular}{|c|c|c|c|c|c|}
\hline & $(1)$ & $(2)$ & 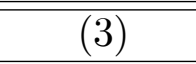 & 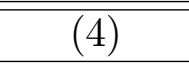 & $\overline{(5)}$ \\
\hline & \multicolumn{5}{|c|}{ Dependent variable is Children } \\
\hline School & $\begin{array}{c}-0.154^{* * *} \\
(0.0396)\end{array}$ & & $\begin{array}{c}-0.168^{* * *} \\
(0.0319)\end{array}$ & $\begin{array}{c}-0.150 * * * \\
(0.0315)\end{array}$ & $\begin{array}{c}-0.115^{* * *} \\
(0.0220)\end{array}$ \\
\hline Log GDP/worker & & $\begin{array}{c}-0.608^{* * *} \\
(0.0995)\end{array}$ & $\begin{array}{c}-0.585^{* * *} \\
(0.0859)\end{array}$ & $\begin{array}{c}-0.566^{* * *} \\
(0.0816)\end{array}$ & $\begin{array}{c}-0.263^{* * *} \\
(0.0901)\end{array}$ \\
\hline Children $_{t-1}$ & & & & & $\begin{array}{c}0.539 * * * \\
(0.0716)\end{array}$ \\
\hline Mortality 0-15 & & & & $\begin{array}{c}-2.618^{* * *} \\
(0.933)\end{array}$ & $\begin{array}{c}-1.252^{*} \\
(0.656)\end{array}$ \\
\hline Mortality $15-60$ & & & & $\begin{array}{c}2.592^{* * *} \\
(0.639)\end{array}$ & $\begin{array}{c}0.973^{* *} \\
(0.400)\end{array}$ \\
\hline Time Fixed Effects & Yes & Yes & Yes & Yes & Yes \\
\hline State Fixed Effects & Yes & Yes & Yes & Yes & Yes \\
\hline \# of States & 48 & 48 & 48 & 48 & 48 \\
\hline \# of Observations & 687 & 665 & 665 & 661 & 633 \\
\hline
\end{tabular}

Notes: The table reports OLS estimates. The unit of observation is US state over the period 1840-1980. The dependent variable is the number of children ever born by a white woman. The explanatory variables are defined in the Data Appendix. Constants are not reported. Standard errors clustered by state in parentheses.

*** $\mathrm{p}<0.01,{ }^{* *} \mathrm{p}<0.05,{ }^{*} \mathrm{p}<0.1$. 


\section{Table 3-Baseline System GMM estimates}

\begin{tabular}{|c|c|c|c|c|}
\hline & $(1)$ & $(2)$ & $(3)$ & $(4)$ \\
\hline & \multicolumn{4}{|c|}{ Dependent variable is Children } \\
\hline Children $_{t-1}$ & $\begin{array}{c}0.478^{* *} \\
(0.206)\end{array}$ & $\begin{array}{c}0.588 * * * \\
(0.0995)\end{array}$ & $\begin{array}{c}0.767^{* * *} \\
(0.104)\end{array}$ & $\begin{array}{c}0.849 * * * \\
(0.120)\end{array}$ \\
\hline School & $\begin{array}{c}-0.237^{* * *} \\
(0.0709)\end{array}$ & & $\begin{array}{c}-0.302^{* * *} \\
(0.0743)\end{array}$ & $\begin{array}{c}-0.302^{* * *} \\
(0.0683)\end{array}$ \\
\hline Log GDP/worker & & $\begin{array}{c}-0.0984 \\
(0.151)\end{array}$ & $\begin{array}{c}0.258^{*} \\
(0.155)\end{array}$ & $\begin{array}{c}0.426^{*} \\
(0.258)\end{array}$ \\
\hline Mortality $0-15$ & & & $\begin{array}{c}3.550^{* *} \\
(1.633)\end{array}$ & $\begin{array}{l}4.318^{*} \\
(2.348)\end{array}$ \\
\hline Mortality 15-60 & & & $\begin{array}{c}-1.376 \\
(1.082)\end{array}$ & $\begin{array}{l}-2.771 \\
(1.859)\end{array}$ \\
\hline $\operatorname{AR}(1) p$-value & 0.021 & 0.000 & 0.000 & 0.000 \\
\hline $\operatorname{AR}(2) \mathrm{p}$-value & 0.773 & 0.237 & 0.201 & 0.400 \\
\hline Hansen J p-value & 0.475 & 0.005 & 0.332 & 0.265 \\
\hline Time Fixed Effects & Yes & Yes & Yes & Yes \\
\hline \# of States & 48 & 48 & 48 & 48 \\
\hline \# of Observations & 654 & 637 & 633 & 633 \\
\hline
\end{tabular}

Notes: The table reports system GMM estimates. The unit of observation is US state over the period 1850-1980. The dependent variable is the number of children ever born by a white woman. The explanatory variables are defined in the Data Appendix. Columns (1)-(3) use lags 3-7 as instruments, whereas column (4) uses lags 3-4 (all 5 rhs-variables are treated as endogenous). Constants are not reported. Standard errors clustered by state in parentheses.

${ }^{* * *} \mathrm{p}<0.01,{ }^{* *} \mathrm{p}<0.05,{ }^{*} \mathrm{p}<0.1$. 


\section{Table 4-Schooling in the workforce}

\begin{tabular}{|c|c|c|c|c|}
\hline & (1) & $(2)$ & $(3)$ & (4) \\
\hline & \multicolumn{4}{|c|}{ Dependent variable is Children } \\
\hline & \multicolumn{2}{|c|}{ Fixed Effects } & \multicolumn{2}{|c|}{ System GMM } \\
\hline Children $_{t-1}$ & & & $\begin{array}{c}0.673^{* * *} \\
(0.132)\end{array}$ & $\begin{array}{c}0.845^{* * *} \\
(0.167)\end{array}$ \\
\hline School/worker & $\begin{array}{c}-0.275^{* * *} \\
(0.0606)\end{array}$ & $\begin{array}{c}-0.241^{* * *} \\
(0.0497)\end{array}$ & $\begin{array}{c}-0.297^{* * *} \\
(0.0950)\end{array}$ & $\begin{array}{c}-0.159^{* *} \\
(0.0700)\end{array}$ \\
\hline School & & $\begin{array}{c}-0.124^{* * *} \\
(0.0217)\end{array}$ & & $\begin{array}{c}-0.205^{* * *} \\
(0.0762)\end{array}$ \\
\hline Log GDP/worker & $\begin{array}{c}-0.511^{* * *} \\
(0.0768)\end{array}$ & $\begin{array}{c}-0.515^{* * *} \\
(0.0739)\end{array}$ & $\begin{array}{c}0.422 \\
(0.275)\end{array}$ & $\begin{array}{c}0.543^{*} \\
(0.297)\end{array}$ \\
\hline $\operatorname{AR}(1) \mathrm{p}$-value & - & - & 0.001 & 0.000 \\
\hline $\operatorname{AR}(2) \mathrm{p}$-value & - & - & 0.667 & 0.482 \\
\hline Hansen J p-value & - & - & 0.048 & 0.157 \\
\hline Time Fixed Effects & Yes & Yes & Yes & Yes \\
\hline \# of States & 48 & 48 & 48 & 48 \\
\hline \# of Observations & 661 & 661 & 633 & 633 \\
\hline
\end{tabular}

Notes: Columns (1) and (2) report OLS estimates (including state FE). Columns (3) and (4) report system GMM estimates. The unit of observation is US state over the period 1840(1850)-1980. All regressions include the mortality variables: Mortality 0-15 and Mortality 15-60 (not reported). The dependent variable is the number of children ever born by a white woman. The explanatory variables are defined in the Data Apppendix. Columns (3) and (4) use lags 3-7 as instruments (all rhs-variables aretreated as endogenous). Constants are not reported.

Standard errors clustered by state in parentheses.

*** $\mathrm{p}<0.01,{ }^{* *} \mathrm{p}<0.05,{ }^{*} \mathrm{p}<0.1$. 
Table 5-Alternative time periods (1) (2)

\begin{tabular}{|c|c|c|c|c|}
\hline & $(1)$ & $\overline{(2)}$ & 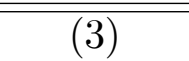 & $\overline{(4)}$ \\
\hline & \multicolumn{4}{|c|}{ Dependent variable is Children } \\
\hline & \multicolumn{2}{|c|}{ Fixed Effects } & \multicolumn{2}{|c|}{ System GMM } \\
\hline & $\begin{array}{c}\text { Pre- } \\
\text { WW2 }\end{array}$ & $\begin{array}{c}\text { 20th } \\
\text { Century }\end{array}$ & $\begin{array}{c}\text { Pre- } \\
\text { WW2 }\end{array}$ & $\begin{array}{c}\text { 20th } \\
\text { Century }\end{array}$ \\
\hline Children $_{t-1}$ & & & $\begin{array}{c}0.680^{* * *} \\
(0.0969)\end{array}$ & $\begin{array}{c}0.713^{* * *} \\
(0.118)\end{array}$ \\
\hline School & $\begin{array}{c}-0.115^{* *} \\
(0.0454)\end{array}$ & $\begin{array}{c}-0.144^{* * *} \\
(0.0256)\end{array}$ & $\begin{array}{c}-0.342^{* * *} \\
(0.0949)\end{array}$ & $\begin{array}{c}-0.0980 * * \\
(0.0391)\end{array}$ \\
\hline Log GDP/worker & $\begin{array}{c}-0.392^{* * *} \\
(0.101)\end{array}$ & $\begin{array}{c}-0.491^{* * *} \\
(0.109)\end{array}$ & $\begin{array}{l}0.280 \\
(0.192)\end{array}$ & $\begin{array}{c}0.321^{* *} \\
(0.142)\end{array}$ \\
\hline $\operatorname{AR}(1) p$-value & & & 0.003 & 0.299 \\
\hline $\operatorname{AR}(2) \mathrm{p}$-value & - & - & 0.001 & 0.366 \\
\hline Hansen J p-value & - & - & 0.278 & 0.030 \\
\hline Time Fixed Effects & Yes & Yes & Yes & Yes \\
\hline \# of States & 48 & 48 & 48 & 48 \\
\hline \# of Observations & 469 & 430 & 441 & 430 \\
\hline
\end{tabular}

Notes: Columns (1) and (2) report OLS estimates (including state FE). Columns (3) and (4) report system GMM estimates. The unit of observation is US state over the period 1840(1850)-1980. All regressions include the mortality variables: Mortality 0-15 and Mortality 15-60 (not reported). The dependent variable is the number of children ever born by a white woman. The explanatory variables are defined in the Data Apppendix. Columns (3) and (4) use lags 3-7 as instruments (all rhs-variables are treated as endogenous). Constants are not reported.

Standard errors clustered by state in parentheses.

*** $\mathrm{p}<0.01,{ }^{* *} \mathrm{p}<0.05,{ }^{*} \mathrm{p}<0.1$. 


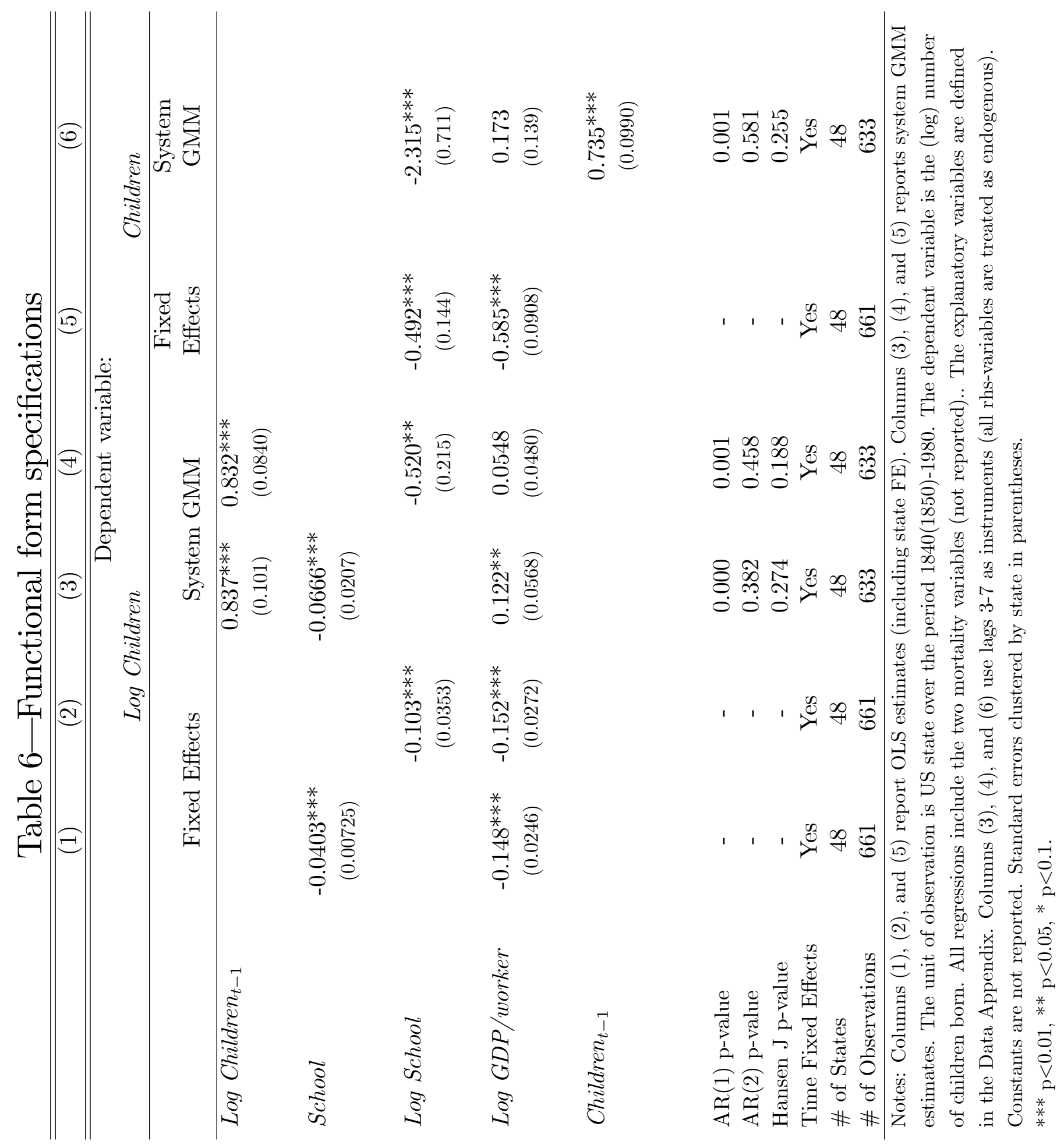


Figure 1: Number of children per women by state

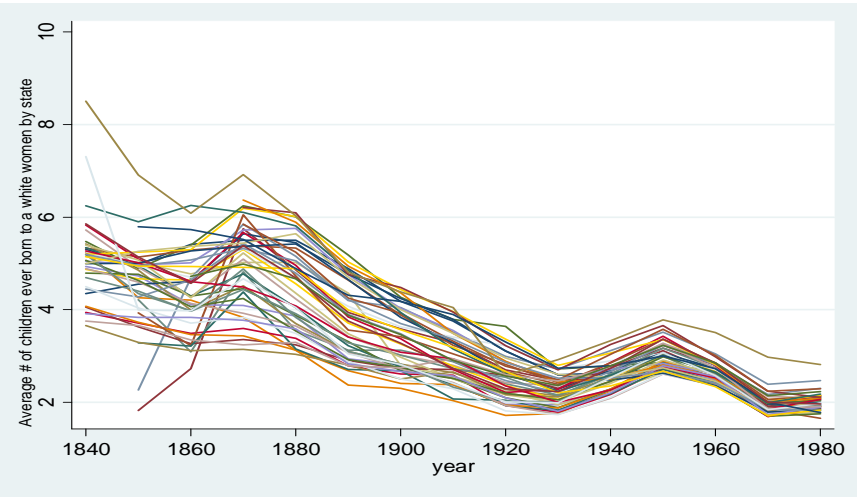

Figure 2: Schooling years by state birth cohort

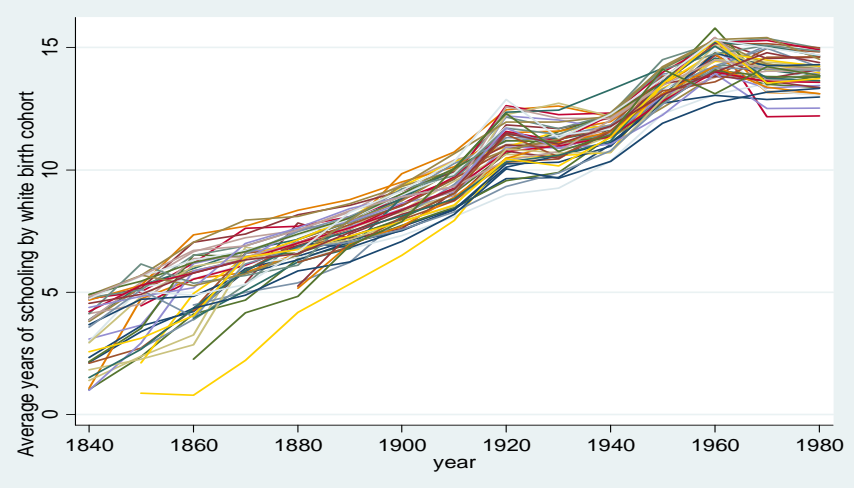

Figure 3: Log GDP per worker

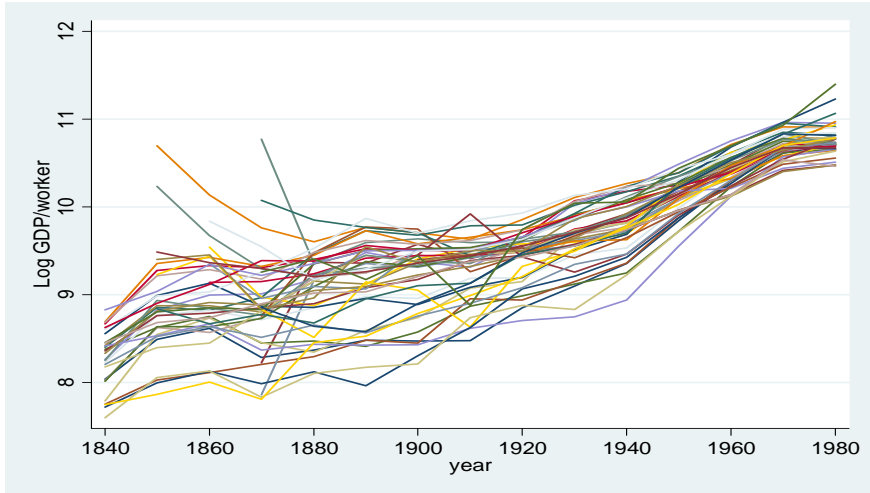


Figure 4: Number of children and schooling years

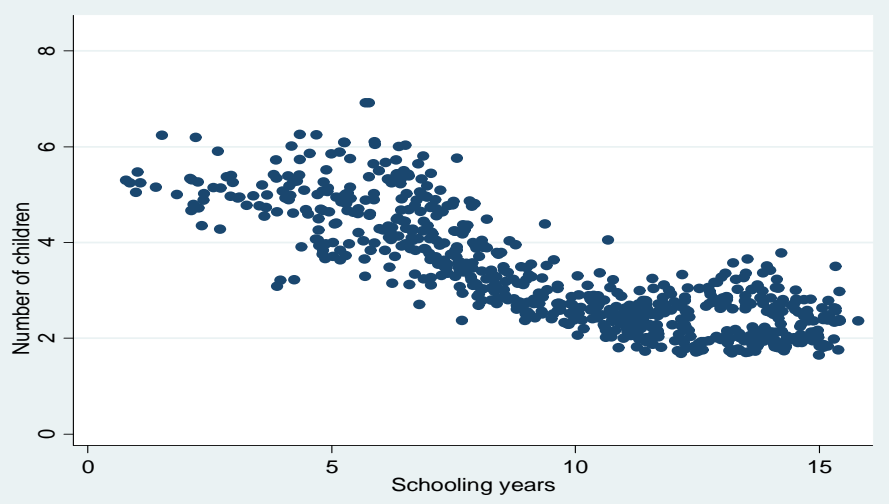

Figure 5: Number of children and log GDP/worker

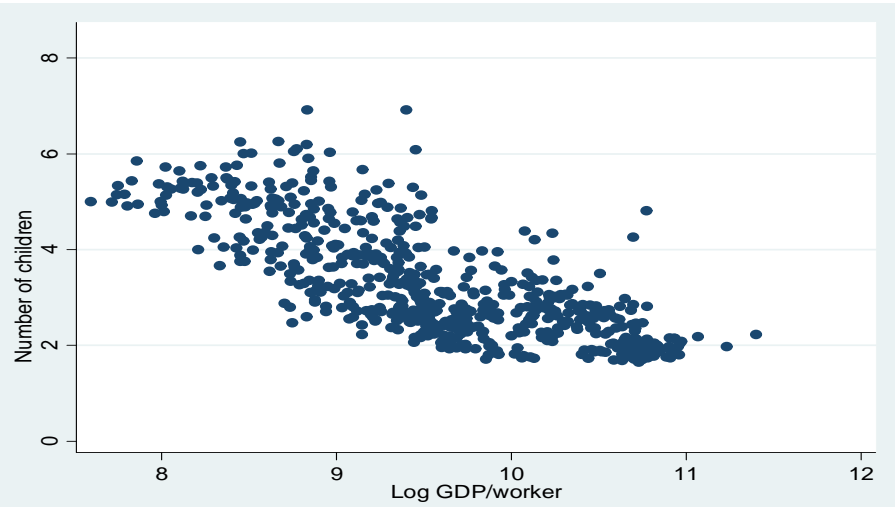




\section{Economics Working Papers}

2013-16: Peter Arendorf Bache and Anders Laugesen: An Industry-Equilibrium Analysis of the LeChatelier Principle

2013-17: $\quad$ Anna Piil Damm and Christian Dustmann: Does Growing Up in a High Crime Neighborhood Affect Youth Criminal Behavior?

2013-18: Christian Bjørnskov and Jacob Mchangama: Do Social Rights Affect Social Outcomes?

2013-19: Benoit Julien, John Kennes, and Moritz Ritter: Bidding for Clubs

2013-20: Ina Charlotte Jäkel: Import-push or Export-pull?

2013-21: Tor Eriksson, Jay Pan and Xuezheng Qin : The Intergenerational Inequality of Health in China

2013-22: Martin Paldam: How do partly omitted control variables influence the averages used in meta-analysis in economics?

2013-23: Ritwik Banerjee: An Evaluation of the Revenue side as a source of fiscal consolidation in high debt economies

2013-24: Nabanita Datta Gupta, Mona Larsen and Lars Brink Thomsen: Do wage subsidies for disabled workers result in deadweight loss? evidence from the Danish Flexjob scheme

2013-25: Valerie Smeets, Sharon Traiberman and Frederic Warzynski: Offshoring and Patterns of Quality Growth: Evidence from Danish Apparel

2013-26: Torben M. Andersen, Jonas Maibom, Michael Svarer and Allan Sørensen: Do Business Cycles Have Long-Term Impact for Particular Cohorts?

2013-27: $\quad$ Martin Paldam: Simulating publication bias

2013-28: Torben M. Andersen and Allan Sørensen: Product market integration, tax distortions and public sector size

2014-01: Leonie Gerhards and Neele Siemer: Private versus Public Feedback The Incentive Effects of Symbolic Awards

2014-02: $\quad$ Casper Worm Hansen, Peter Sandholt Jensen and Lars Lønstrup: The Fertility Transition in the US: Schooling or Income? 